\title{
Contemporary Relevance of Bertrand Russell's Views on Early Childhood Education
}

\author{
Runumi Sharma $^{{ }^{*} \text { iD } \text { and Mamta Aswal }}{ }^{2}$ \\ ${ }^{1}$ S.S.J. University, Almora, Uttarakhand-263601, India \\ ${ }^{2}$ Faculty of Education, S.S.J. University, Almora, Uttarakhand-263601, India \\ *runumisharma3131@gmail.com (Corresponding author)
}

\section{ARTICLE INFORMATION}

Received: January 29, 2021

Revised: March 01, 2021

Accepted: March 05, 2021

Published Online: March 31, 2021

Keywords:

Bertrand Russell, Early childhood education,

E.C.C.E., National Education Policy - 2020

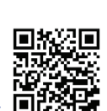

\begin{abstract}
Bertrand Russell's educational thoughts significantly deal with reforming education for school going children and he also supported pre-primary education. He favored early childhood education for physical, intellectual and character development. His emphasis on character development of a child shows the significance of early years of life for development of an individual. This paper aims at exploring Bertrand Russell's thoughts on early childhood education. It is an attempt to understand the significance of early childhood education for the holistic development of the children. Though there are early childhood education is prevalent in our country, but it was not mandatory to get early childhood education till the approval of National Education Policy (N.E.P., 2020). It has included early childhood education in compulsory school education for promoting better learning and well being of a child. It is a qualitative research in which historical method has been used where data has been collected from primary and secondary sources. The finding of the study shows that Bertrand Russell's thought on early childhood education is relevant in present Indian context for developing good values, physical and mental development as well as in future learning. This shows that the encouragement to early childhood education and Bertrand Russell's thoughts on early childhood education would be helpful for holistic development of children.
\end{abstract}

\section{Introduction}

Bertrand Russell, one of the great philosophers of $20^{\text {th }}$ century made an immense contribution in the field of philosophy, logic, mathematics, language and education. He has contributed in the field of education by giving his valuable thoughts and suggestions on various aspects of education. Russell's thoughts are still relevant in reforming education. His educational thoughts may give new direction to education. He accepted the need of understanding child psychology in education. He considered first six years important in the life of a child (Shah, 2014). He emphasized on educating the child according to psychological needs. He has given his views on various aspects of education for reforming education. His views were mainly for schools students. As he wrote about educational matters throughout his life, he was clear on making best education for small children. He wrote a book "On Education" especially for parents so that parents can think of best education and welfare for children.
He suggested nursery school for the children of two years and above so that they will learn many things in the company of other kids. He himself wrote "I believe that even the best parents would do well to send their children to a suitable school from the age of 2 onwards, at least for part of the day- provided such a school existed in their neighborhood" (Russell, 1926).

\section{Bertrand Russell's Thought on Early Childhood Education}

Bertrand Russell strongly favored early childhood education. He considered early childhood as an important stage for both - medical and psychological aspects. He believed that a child should be sent to a nursery school after his/her two years of age. Russell accepted both school and home for kids. School and home have their own advantages and disadvantages. He accepted the positive influence of home in the education of a child and also accepted that home environment play a vital role in the education of a child, but he 
emphasized that a child gets suitable environment in school for their growth and development (Pandey \& Sharma, 2008). He favored nursery schools for the children of all kind of parents- poor, ignorant and over worked (Russell, 1926). He accepted that though the children living in rural areas can go late to nursery schools but, children living in urban areas should join nursery schools at early age ( 2 years). The children of rural areas get an opportunity to live in natural environment but, the children of urban areas does not get space to enjoy in natural environment. In nursery schools, the children of urban areas get the freedom of noise, movement, space and friends (Russell, 1970). They usually don't get these opportunities in their area. Russell while talking about home versus school for a kid believed that school is better than home for these reasons (Russell, 1970). According to Russell, "no urban home however excellent, can supply what is necessary for the healthy, mental and physical growth of a child" (Russell, 1926). It is difficult to provide, space, fresh air and environment at home for the benefit of young children. Rich may provide the facilities to children but poor parents can't. When the children of rich parents get the opportunities for their growth and development at home, they may develop feeling of pride or superiority. It is better to send the kids from two years of age to nursery schools for all parents. They must be sent for some time in a day in neighborhood school. He believed that if nursery education become universal than, it will help in the physical and mental development of all children irrespective of them being rich or poor. He accepted that at that time, only rich people were giving nursery education to their kids. He believed nursery education has a place "between early training of character and subsequent giving of instructions" (Russell, 1926). He emphasized on the moral education of a child. He believed in the formation of character in early childhood so, he supported education for character formation in early years. He opined that character of a child start developing with the birth of a child and the formation of a character is complete by the age of six. He emphasized on the "physical, emotional and intellectual care of the young" (Russell, 1926). This would develop the good character of young child. He wanted to develop characteristics such as "vitality, courage, sensitiveness and intelligence" (Russell, 1926). He wanted to develop the vitality, courage and sensitiveness in early childhood period. These qualities will develop the character at home or in nursery school. After the age of six years he stressed on intellectual development (Park, 1981). He believed that if the character is developed properly in first six years, then the intellectual education will further develop the character of a child. He wanted to form these characteristics through education. These qualities are helpful in the psychological development of a child. The early education of a child helps to learn good habits. He wanted to develop both health and character in young children but he dealt with character only.

\section{Need and Importance of Early Childhood Education}

The early childhood education caters to the age group 3 to 5 years. It is the early childhood education which is needed to develop child's physical, emotional, social and cognitive needs which helps in the holistic development of child and for a bright future. There are four development areas in early childhood education i.e. physical, social, emotional and cognitive development (E.C.C.E., 2012). Early childhood education helps in the brain development of the child by developing their skills through various activities. Maria Montessori believed that the child develop physically and psychologically in the age group from birth to six years (Montessori, 1967). It is also known as pre- school education or nursery education. This education prepares a child for elementary education and influence positively in the whole education system. Maria Montessori a great educationist who is known for Montessori Method advocated early childhood education. She believed the goal of education is to realize the values o person and the development of whole mankind (Montessori, 1972). This is possible when we pay attention to education of a child from their early childhood. As each and every country have concerned about economic growth and productivity, it is the early childhood education which has direct concern in contributions towards the development of future citizen (Calman \& Whelan, 2005). Early childhood education is important as it gives the child place to socialize where they can get away with their shy nature and develop confidence by socializing with other children or teacher. In the school a child learns 
to share their toys or other things with other children. Learning through activities prepares them as well as help in future learning. It helps in their language development, development of motor or sensory skills and to explore the world outside their home. The main objective of E.C.C.E. is to enable a child to know his/her maximum potential, and to prepare them for schools (N.C.E.R.T., 2006). Pre-school education not only gives importance to the training of minds (intellectual development) but, to educate a child in different aspects of personality (socio-emotional development). Hendrick, (1980) opined that the most important reason for sending a child to pre-school is to make them learn to get familiarize with others and the teachers accept that this competency is very important.

\section{Status of Early Childhood Education in India at Present Time}

India, a country of values acknowledged the importance of early years in a child's life. Our country stresses on inculcating values and social skills in early years of childhood. Earlier, it was developed at home; when joint family system was in vogue. Now, when both parents are working it is the nuclear family that is prevalent in our country, we accepted the need of early childhood care and education for providing suitable environment for their growth and development. In our country, many Indian philosophers such as Gandhi, Vivekananda, Tarabai Modak, Girju bhai, Aurobindo and Rabindra Nath Tagore acknowledged the importance of early childhood care and education. They believed that early childhood education is helpful for laying the foundation for all round development and for developing full potential of a child. Maria Montessori visited India in the year 1939 which laid the foundations of preschool education in our country. The teachers were trained for teaching according to Montessori Method. In the post independent India many communities and commissions has focused on early childhood education. The committee on early childhood education in the year 1953 accepted the limitations of providing early childhood education at home and recommended to include pre-primary education in the primary schools. Kothari Commission (1964), National Policy on Education (1986), Program of Action (1993) stressed on expansion of early childhood education in India. The $12^{\text {th }}$ five year plan accepted the significance of early childhood education. The provision of early childhood education in India is provided by public, private and non-government organizations (W.C.D., 2007). The Government of India has given approval to National Early Childhood case and Education (E.C.C.E.) policy in the year 2013. It consists of National Curriculum Framework and Quality standards for E.C.C.E. It is the Ministry of Women and Child Development (M.W.C.D.) which makes a policy on E.C.C.E. E.C.C.E. in India comes under Integrated Child Development Services (I.C.D.S.) Scheme. One of the components of I.C.D.S. is pre-school. In India, Early childhood education is mainly provided by Anganwadis (under I.C.D.S.). There are various nursery schools, Montessori schools, crèches, day cares, preparatory schools, play schools, balwadis and kindergartens which are established throughout India to provide pre-school education (Draft National Early Childhood Care and Education (E.C.C.E.) policy, 2012, Ministry of Women and Child Development, Government of India). It is well accepted that the development of a child in first six years is higher than rest of the life. The National E.C.C.E. Curriculum Framework 2014 emphasized on the care, health, nutrition and well being of young children (N.C.E.R.T., 2019). This curriculum is for children below 6 years of age. This is designed to encourage care, early learning and to prepare them for primary education. It is to develop the child holistically by developing their physical, social, emotional, intellectual and moral aspects (National Early Childhood Care and Education (E.C.C.E.) Curriculum Framework, Ministry of Women and Child Development).

\section{Relevance of Bertrand Russell's Thought on Early Childhood Education in Present Indian Context}

Our country has pursued on the need of early childhood care and education in National Education Policy, 2020. Early childhood education was functioning in our country, but it was not a part of main stream education. National Education Policy, 2020 recognized the importance of Early Childhood Care and Education for ensuring growth and development of the children. It accepted that crores of socio-economic disadvantaged children especially in the age group of 3-6 years are not receiving quality Early Childhood 
Care and Education. N.E.P., 2020 declared the aim of E.C.C.E. is "physical and motor development, cognitive development, socio emotional- ethical development, cultural/ artistic development and the development of communication and early language, literacy and numeracy" (Pandey and Sharma, 2008).

It talks about providing activity based or play-way learning to a child before reaching class-I in order to develop cognitive, affective and psychomotor domain and literacy and numeracy at early years. Bertrand Russell's thought on pre-school education is very relevant in present context as it will help in the physical and mental development of children. It will help in forming good values in children and will prepare them for adjustment in school later on. This would help the children of our country in their socio-emotional development in early years. The good habits learnt by students in pre-school education would help them in the formation of character and its strengthening. They will get companionship and place to play in pre-school. The play based or activity based environment of school helps the child to develop positive attitude for learning and school. Russell's view that a child should be sent to neighborhood schools for early childhood education is relevant in present time because the children will get space, classmates and enjoy with other students for few hours in a neighborhood schools.

\section{Conclusion}

Bertrand Russell was among one of the educationists who gave his voice for the support early childhood education. He considered it important not only for physical and mental development but also for moral development of a child. Our education system has included pre-school education in the mainstream education by approving National Education Policy, 2020. This will bring the children of 3-5 years of age in compulsory school education. This will help in the overall development of a child and prepare them for future by developing their physical and mental abilities as well as their character by inculcating good habits among them.

\section{Acknowledgement}

The authors are thankful to Dean, Faculty of Education, S.S.J. University, Almora for the facilities provided during the course of study.

\section{Authorship Contribution}

First Author - collection and analysis of primary and secondary sources of data.

Second Author - guidance and review of papers.

\section{References}

Calman, L.J., \& Whelan, L.T. (2005). Early childhood education for all. New York; Legal Momentum.

E.C.C.E., (2012). Early Childhood Care and Education, UNESCO. www.unicef.org./eapro/End_Decade_ note_education_for_all_new.pdf

Hendrick, J. (1980). The whole child. $2^{\text {nd }}$ Edn. New trends in Early childhood, Missouri:C.V.Mosby Co.

Montessori, M. (1967). The absorbent mind. New York: Delta.

Montessori, M. (1972). Education and peace. Chicago. Henry Regnery Company.

N.C.E.R.T. (2006). Position paper national focus group on early childhood education. www.ncert.nic.in/new_ ncert_ncert/rightside.

N.C.E.R.T. (2019). The Pre-school Curriculum. December, 2019.

N.E.P. (2020). National Education Policy. Ministry of Human Resource Development, Government of India.https://www.mhrd.gov.in>files. Accessed 28 April 2017.

Pandey, R.S. and Sharma, U.R. (2008). On Education, Anubha, Publishing House, Allahabad.

Park, J. (1981). Bertrand Russell on Education, George Allen and Unwin Ltd. London.

Russell, B. (1926). On Education, George Allen and Unwin Ltd. London.

Russell, B. (1970). Education and Social Order, George Allen and Unwin Ltd. London, pp.- 76.

Shah, M.I. (2014). Plato and Russell: On Education (An Appraisal). Al-Hikmat, 34, 17-24.

W.C.D., (2007). National Report on a World fit for children. Ministry of Women and Child Development, Government of India. 


\section{旬 CHITKARA}

\section{Issues and Ideas in Education}

Chitkara University, Saraswati Kendra, SCO 160-161, Sector 9-C, Chandigarh, 160009, India

Volume 9, Issue 1

Copyright: [〔 2021 Runumi Sharma and Mamta Aswal] This is an Open Access article published in Issues and Ideas in Education (Issues Ideas Educ.) by Chitkara University Publications. It is published with a Creative Commons Attribution- CC-BY 4.0 International License. This license permits unrestricted use, distribution, and reproduction in any medium, provided the original author and source are credited. 